DOI: $10.1590 / 1089-6891 v 17 i 123998$

MEDICINA VETERINÁRIA

\title{
USE OF HYDROALCOHOLIC EXTRACT OF Schinus terebinthifolius Raddi IN PRE- AND POST-MILKING ANTISEPSIS OF THE TEAT IN DAIRY COWS
}

\section{UTILIZAÇÃO DO EXTRATO HIDROALCOÓLICO DE Schinus terebinthifolius Raddi NA ANTISSEPSIA DO TETO PRÉ E PÓS-ORDENHA EM BOVINOS DE LEITE}

\author{
Ângela Faccin ${ }^{1 *}$ \\ Luiz Filipe Damé Schuch ${ }^{1}$ \\ Diane Bender Almeida Schiavon ${ }^{1}$ \\ Carolina Lambrecht Gonçalves ${ }^{1}$ \\ Fernanda Voight Mota ${ }^{1}$ \\ Lisiane Ferreira Lessa ${ }^{1}$
}

${ }^{1}$ Universidade Federal de Pelotas, Faculdade de Veterinária, Pelotas, RS, Brasil.

*Autora para correspondência - angefaccin@gmail.com

\begin{abstract}
Medicinal plants have been used for centuries as an alternative treatment for health problems. Schinus terebinthifolius Raddi is a median tree that belongs to the Anacardiaceae family. The antibacterial effect of leaves extract of this plant has already been demonstrated. The objective of this study was to test a substance derived from this plant to be used in pre- and post-milking teat antisepsis. The hydroalcoholic extract of Brazilian pepper tree was used in opposite quarters for twelve consecutive weeks, and commercial iodine was used as control. None of the indices analyzed - black background mug, CMT, intramammary infections, skin health, and teat health - showed a statistical difference between the treatments, suggesting that the plant extract can be used in pre- and post-milking teat antisepsis, as a substitute for conventional products for herds in an agroecological production system. Keywords: medicinal plants; milk; natural antiseptic; organic production.

\section{Resumo}

As plantas medicinais têm sido usadas há séculos como alternativa de tratamento para problemas de saúde. Schinus terebinthifolius Raddi ou aroeira é uma árvore mediana pertencente à família Anacardiaceae. O efeito antibacteriano de extratos de folhas dessa planta já foi demonstrado. O objetivo deste estudo foi testar o extrato de Schinus terebinthifolius Raddi na antissepsia de tetos pré e pós-ordenha. Foi utilizado extrato hidroalcoólico da aroeira, tendo como controle iodo comercial, em quartos opostos, durante doze semanas consecutivas. Nenhum dos índices analisados - caneca de fundo escuro, CMT, novas infecções intramamárias, "saúde da pele e do esfíncter do teto" demonstraram diferenças estatísticas entre os tratamentos usados, sugerindo que o extrato da planta pode ser usado na pré e pós-ordenha para desinfecção de tetos, como substituto dos produtos convencionais, para rebanhos em sistema de produção orgânica.

Palavras-chave: desinfetante natural; leite; plantas medicinais; produção orgânica.
\end{abstract}




\section{Introduction}

Medicinal plants have been part of our society in preventing diseases since the dawn of civilization, and developing countries have used these plants for centuries as an alternative treatment for health problems. ${ }^{(1,2)}$ Farmers have reported the use of medicinal plants to increase milk production and to treat bovine mastitis. ${ }^{(1)}$ The employment of these natural products has decreased or even disappeared from the medical indication with the advent of modern medicine ${ }^{(2)}$ because in most cases lack explanation scientific evidence. ${ }^{(3)}$ The Ethnoveterinary seeks to rescue the traditional knowledge by connecting it with scientific knowledge. ${ }^{(4)}$

Among the health problems that affect dairy cattle, infectious mastitis is the most prevalent disease. It reduces milk production, causes losses by milk disposal and the death of animals, and increases treatment costs. Sanitization of the environment and equipment, as well as udder antisepsis after milking, prevents this disease, by reducing the number of pathogenic microorganisms. Teats antisepsis is a practice incorporated into the routine of milking, and it is important to control mastitis. ${ }^{(5)}$ However, the biggest challenge for the dairy industry is the pressure for reducing the use of antibiotics in foodproducing animals. ${ }^{(2)}$ The indiscriminate use of these products may contribute to the establishment of persistent infections, which is a limiting factor for the treatment of bovine mastitis. ${ }^{(1)}$

Schinus terebinthifolius Raddi, Brazilian peppertree, is a median tree of the Anacardiaceae family. ${ }^{(6)}$ This tree is native to South and Central America and grows in tropical and semitropical regions of the United States and Africa as an ornamental garden tree. ${ }^{(7)}$ In Brazil, it occurs from the Atlantic rainforest to the state of Rio Grande do Sul. ${ }^{(6)}$ Indigenous people have used almost all parts of S. terebinthifolius, including leaves, bark, fruit, seeds, resin, and oleoresin, as medicine.(7) The ethnobotanical literature cites the use of the bark, based on popular tradition, as a decoction, especially by women at postpartum, as an anti-inflammatory and healing agent, or as homemade medicine for treating diseases of the urinary and respiratory systems. ${ }^{(6)}$ The in vitro antibacterial action of the tinctures extract of this plant has been proven against on dental biofilm forming bacteria. ${ }^{(8)}$

The importance of medicinal plants can be attributed to accessibility, as well as the confidence in phytotherapy, according to the witnessed positive effects from their use. ${ }^{(1)}$ The obtainment of milk in quantity and quality based on agroecology depends on solutions to the livestock health problems through renewable alternatives, in which the use of medicinal plants has high potential. ${ }^{(4)}$ The term 'organic' refers to animal and plant foods produced without the use of fertilizers, pesticides, insecticides, antimicrobials, antiparasitics, transgenics, or any other drug having residues harmful to human health, including products for agricultural use intended for dairy animals. ${ }^{(9)}$ The aim of this study was to develop and test a Schinus terebinthifolius Raddi-based product, with antibacterial action to be used in pre- and post-milking teat antisepsis.

\section{Material and Methods}

The leaves were collected in June 2012, in a single day, in the morning, before ten o'clock. The trees were located in Campus Capão do Leão of the Federal University of Pelotas, municipality of Capão do Leão, state of Rio Grande do Sul, Brazil, in a radius of $1 \mathrm{~km}$ from the geographic references $31^{\circ} 48^{\prime} 08^{\prime \prime} \mathrm{S} 52^{\circ} 24^{\prime} 55^{\prime \prime} \mathrm{O}$, average altitude of 17 meters. The trees were healthy, free from disease and insect infestation.

Collected samples were sent to the Laboratory of Bacteriology (DVP/FV/UFPel), where branches and stems were manually separated, remaining only the leaves. The leaves dried for fifteen days on screens in a cool and airy place, free from insects and bad weather.

Dried leaves of each tree were sent to the Herbarium of the Institute of Biological Sciences of the Federal University of Pelotas for identification and conservation.

The hydroalcoholic extract of Schinus terebinthifolius Raddi was made from the leaves of the plant and cereal alcohol at a density of $70^{\circ} \mathrm{GL}$, in a ratio of $1: 10(\mathrm{~g} / \mathrm{mL})$. The leaves remained in contact 
with alcohol for two weeks, with twice a day agitation. After this period, filtering was performed with four folds filter gauze, the initial volume was reset with $70^{\circ} \mathrm{GL}$ cereal alcohol and the extract was stored in an amber bottle free of sunlight. ${ }^{(5)}$ A dilution in water (1:5) was made to use the solution, immediately before milking

For microbiological identification of new intra-mammary infections (NIMI), weekly samples of milk $(5 \mathrm{~mL})$ were individually collected from all mammary quarters of milking animals, after teat asepsis with cotton soaked in $70^{\circ} \mathrm{GL}$ alcohol. The samples were put in properly identified sterile test tubes, packed in isothermal boxes with reusable ice, and were sent to the Laboratory of Bacteriology of the Faculty of Veterinary of Federal University of Pelotas (UFPel). The milk samples were plated in Petri dishes with $5 \%$ defibrinated sheep blood agar and incubated at $37{ }^{\circ} \mathrm{C}$. The reading was made after 24 and 48 hours, observing the cultural characteristic of the colonies (morphology, pigment production, and hemolysis) and morpho-tinctorial characteristics of the microorganisms by Gram staining, allowing a preview of bacteria involved in the process. ${ }^{(10)}$

To assess the health of the teat skin under the use of the extract we collected, every two weeks, assessment data concerning teat scores, referring to the sphincter and the skin at the proximal and distal portions of the mammary gland, according to classification by Neijenhuis. ${ }^{(11)}$

The experiment was conducted in a commercial dairy production unit during 12 weeks. The number of animals in milking oscillated between 64 and 73 cows in different periods of lactation, totaling 95 animals of Jersey and Holstein breeds under extensive farming with mechanized milking performed twice a day.

For teat antisepsis before and after milking, we proceeded as follows: on the left mammary quarters we applied the Schinus terebinthifolius Raddi extract solution and on the right quarters, we applied commercial iodine (Mastin Plus ${ }^{\circledR}$ ), in all milking during the entire period of the experiment. Weekly data regarding clinical and subclinical mastitis were collected, using black background mug test and California Mastitis Test (CMT). ${ }^{(12)}$

The occurrence of new intramammary infections (NIMIs) was assessed by the number of days free of infection in each quarter (i.e. the number of days negative for bacterial culture), by calculating the number of quarters exposed and previously free of IMI as the denominator and the number of new cases used as the numerator. A new case was considered when the culture was positive for Staphylococcus spp., coagulase positive, or for Streptococcus spp., in the sample of that mammary quarter. This index was corrected for 1000 quarters/day. The exclusion criteria were: SCP or Streptococcus spp. infection at the beginning of the work, in the week zero and up to two weeks after a microbiologically positive collection. Animals with two successive negative collections were considered cured and were reintroduced in the free of infection counting days. ${ }^{(5)}$

Statistical analysis of results was performed by evaluation of qualitative data (total of new IIMs by SCP or Streptococcus spp., and clinical and sub-clinical mastitis) by chi-square test, using Epi Info 7.0 and non-parametric data program.

\section{Results and Discussion}

The results regarding the evaluation of California Mastitis Test (CMT) were statistically similar between treatments (Figure 1). There were some differences between the values; however, these differences were not statistically significant. The prevalence of negative results for this test varied concerning the values of $\mathrm{p}$, with $\mathrm{p}=0.12$ at the $8^{\text {th }}$ week and $\mathrm{p}=1$ at the $5^{\text {th }}$ and $7^{\text {th }}$ weeks.

The number of clinical mastitis cases totaled 26 during the two weeks evaluated. Ten cases in the control group were treated with iodine, and 16 cases in the experimental group were treated with plant extract, with no statistical difference between the two groups $(p=0.33)$. Correcting these numbers for cases of clinical mastitis per thousand-quarters in risk per day, we have 0.965904 for the control group and 1.53198 for the treatment group, with no statistical difference between the treatments.

The new intramammary infections caused by Staphylococcus spp. coagulase positive and Streptococcus spp. are in Table 1, where we can observe the two treatments, the treatment with commercial iodine on the right, and the treatment with the plant extract on the left. Concerning the total number of new 
intramammary infections, we noticed that there was no difference between the two treatments. No cases of IMI by Gram-negative bacteria were noticed during the experiment.

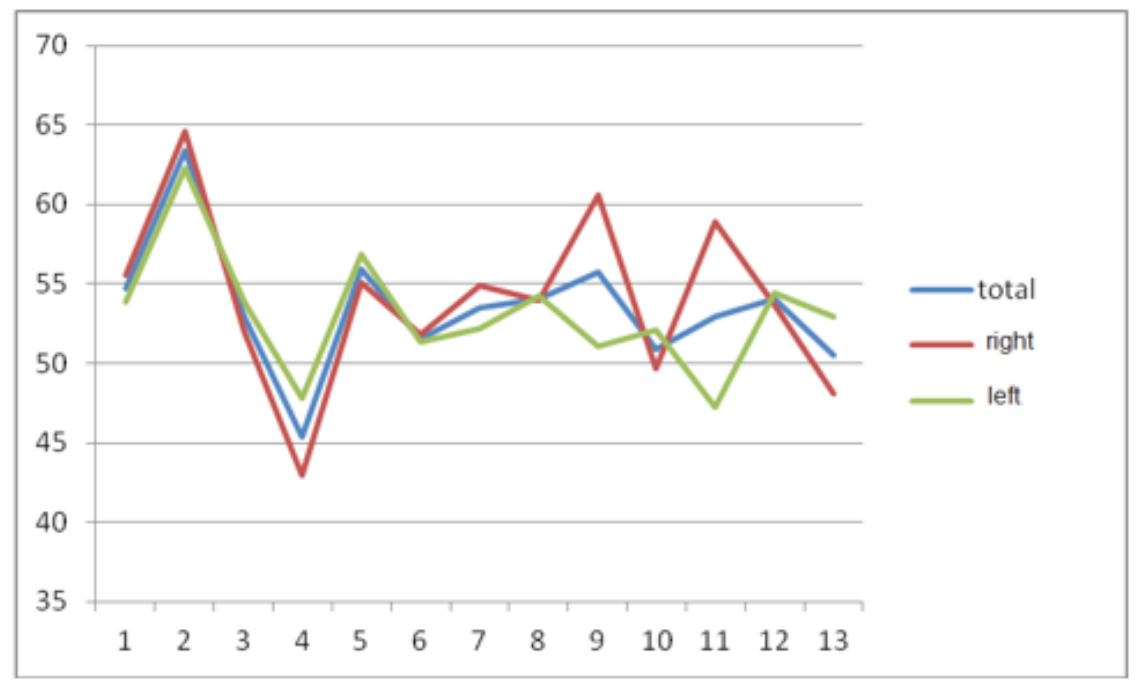

Figure 1: Incidence of the thirteen CMT negative samples.

Right: Treatment with iodine commercial control; Left: Experimental treatment with the Schinus terebithifolius Raddi extract.

Table 1: Incidence of new intramammary infections caused by Staphylococcus spp. coagulase positive and Streptococcus spp. in both treatments, control treatment with iodine commercial and experimental treatment with extract of Schinus terebithifolius Raddi

\begin{tabular}{|c|c|c|c|}
\hline & $\begin{array}{l}\text { Treatament } \\
\text { control }\end{array}$ & $\begin{array}{l}\text { Treatament } \\
\text { experimental }\end{array}$ & $\mathbf{p}$ \\
\hline $\begin{array}{l}\text { NIIM by Staphylococcus } \\
\text { coagulase positive* }\end{array}$ & 3,11 & 4,44 & 0,20 \\
\hline NIIM by Streptococcus spp. * & 2,74 & 3,12 & 0,67 \\
\hline Total & 5,86 & 7,32 & 0,29 \\
\hline
\end{tabular}

The health of the teat sphincter had a reduction in the score up to the third analysis in both treatments, remaining stable in the other weeks, as we can see in Figure 2. There was no significant difference in skin score during the period of the treatment. There was no difference in the analysis (skin and teat sphincter health) in treatments comparison. These data support the little or no toxicity of the product used in pre- and post-milking.

Bovine mastitis is caused mainly by bacterial agents, most common of which are those belonging to the genera Staphylococcus spp., Streptococcus spp., and Corynebacterium spp. ${ }^{(13)}$ In a study of milk produced in an organic production system, Ribeiro ${ }^{(9)}$ isolated mainly Staphylococcus spp. and Streptococcus spp. from animals with mastitis. The organic milk production associates low-cost over time because it allows a partial independence of the farmer of external inputs and medicines, increasing profitability, besides being an attractive product for the consumer who knows that the benefits of organic food are biologically superior ${ }^{(14)}$.

Farmers and veterinarians employ topical use of herbal solutions or ointments, or the oral administration of green or dry plants. ${ }^{(4)}$ The use of herbal medicines as a pre- and post-milking antiseptic is little reported, making this type of study an option to test the use of medicinal plants in the control of mastitis in organic production systems. 

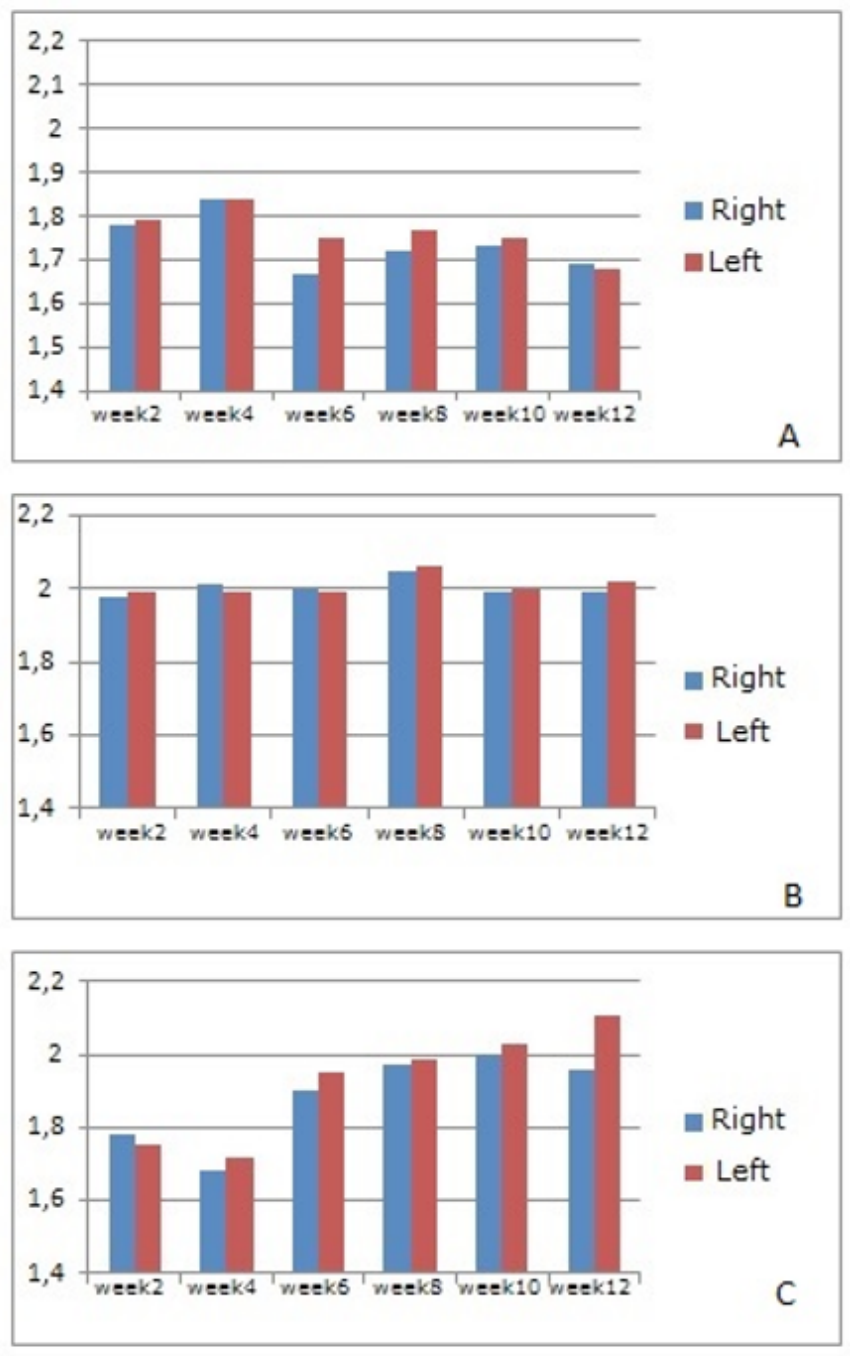

Figure 2: Average score biweekly skin health lower portion (A), the upper portion (B) and sphincter $(\mathrm{C})$ from the ceiling in different treatments.

Right: Treatment with iodine commercial control; Left: Experimental treatment with extract of Schinus terebithifolius Raddi.

Mastitis is an inflammatory process usually caused by bacteria and it has the greatest economic impact in dairy farming worldwide. ${ }^{(15)}$ The definitive diagnosis of an intramammary infection requires the isolation of pathogenic bacteria from milk samples. As these infections are generally followed by an influx of leukocytes into milk, an increase in somatic cells count has been widely used as an indication of mastitis. ${ }^{(16)}$ We used California Mastitis Test (CMT) to detect subclinical mastitis in the property. It is a test widely used to determine the disease status of lactating animals. It is simple, inexpensive, and used as a rapid screening test. ${ }^{(17)}$ According to the evaluation of inflammatory markers in mastitis diagnosis done by Dalla Libera, ${ }^{(15)} \mathrm{CMT}$ is as a reliable tool for mastitis diagnosis. In our study, we obtained the prevalence values of positive CMT every week, ranging between 36.6 and $54.6 \%$. Bhutto et al. ${ }^{(16)}$ found positive CMT around $47 \%$ in a certain region of Germany. In a study in the municipality of Botucatu, state of São Paulo, Brazil, Langoni ${ }^{(14)}$ evaluated cytological and microbiological aspects of milk in rural properties with an organic production system, and found $44 \%$ positive CMT, similar to vthe alues found in our study, over the weeks evaluated. These findings showed that except for the weeks of oscillations, our results reflect the reality of Brazil. However, Schiavon, ${ }^{(5)}$ in a study conducted in the same region, found values near $29 \%$. This difference may be 
justified by the extended period of drought that has occurred that year, decreasing the food supply and quality, since the animals were reared in an extensive production system, generating a high-stress situation.

The duration of infections in cows is an important point that should be considered because the faster mastitis cases are eliminated the greater are the chances of success of control programs. ${ }^{(18)}$ Gundelach ${ }^{(19)}$ reported that Staphylococcus spp. coagulase negative caused approximately $85 \%$ of new intramammary infections. Park ${ }^{(20)}$ also reported a greater occurrence of these pathogens in new intramammary infections followed by Staphylococcus aureus and Streptococcus spp.. In our study, we found greater isolation of Staphylococcus spp. coagulase positive in cases of new intramammary infectious followed by Streptococcus spp..

Schiavon $^{(5)}$ tested a Tagetes minuta-based solution for post-milking antisepsis in lactating cows, and reached numbers almost five times higher than ours when we evaluated the incidence of new intramammary infections per a thousand-quarters a day. Moreover, there was no significant difference between the two treatments in this study, both the plant extract and the commercial product obtained similar results in controlling NIMI.

Plant-based products are a major source for alternative therapy; herbal medicines have been explored for centuries by several communities because of their properties against a broad range of human and animal diseases. ${ }^{(3)}$ The importance of using medicinal plants can be attributed to affordability, as well as to the trust in phytotherapy achieving positive results when using herbal medicines. ${ }^{(1)} \mathrm{We}$ can state that the leaves of Schinus terebinthifolius Raddi can be used for antisepsis in milking because the incidence of NIMI was similar for both treatments. Silva, ${ }^{(21)}$ in an in vitro study, reported the antibacterial action of the essential oil from leaves of this plant against Staphylococcus spp. coagulase positive isolated from external otitis in dogs.

An antiseptic solution should be appropriate to the problem situations in which will be employed. For using in teats antisepsis in bovine milking routine, it must be effective against the agents involved in mastitis, with time action compatible with animal handling, and low susceptibility to intervening factors, such as the presence of organic matter, $\mathrm{pH}$, and support. Moreover, it should not have side effects on animal skin and do not leave residues in milk. ${ }^{(4)}$ Age-related anatomical changes of the teat lead to negative effects on local resistance (e.g. increase in diameter of the teat canal, diminished function of the teat canal sphincter), and reduced resistance with increasing age are possible reasons for an increased risk of infection. ${ }^{(19)}$

In this study, there was no significant difference in skin scores when treatment time was analyzed, suggesting low or no toxicity of the product used in pre- and post-milking, when comparing fortnight results in each one. According to this, we can state that the hydroalcoholic extract of Schinus terebintifolius Raddi can be used as an antiseptic in pre- and post-milking because it showed no toxicity when compared to the conventional treatment with commercial iodine. However, at the beginning of the experiment, there was a worsening in the scores of both treatments. According to Neijenhuis, ${ }^{(11)}$ it may be due to a hyperkeratosis of the teat duct orifice, which is the result of a normal physiological process of adaptation at the beginning of lactation. On the other hand, after repeated milking, the teatend tissue shows changes that appear as a crown around the teat orifice, such changes may result from mechanical forces exerted by the vacuum during milking. ${ }^{(11)}$ Silva ${ }^{(21)}$ performed toxicological tests of the essential oil from the leaves of Schinus terebnthifolius Raddi in laboratory animals and observed no changes.

\section{Conclusion}

In this study, there was no difference in the incidence of new intramammary infections when comparing the two treatments, as well as no evidence of toxicity of plant extract on teat skin was observed. These results allows us to say the hydroalcoholic extract of Schinus terebinthifolius Raddi can replace commercial iodine in teat antisepsis in milking. 


\section{Acknowledgements}

Cooperativa Vista Alegre (COOPAVA), CAPES, Embrapa CPACT.

\section{References}

1. Diaz MAN, Rossi CC, Mendonça VR, Silva DM, Ribon AOB, Aguilar AP, Muñoz GD. Screening of medicinal plants for antibacterial activities on Staphylococcus aureus strains isolated from bovine mastitis. Revista Brasileira de Farmacognosia. 2010; 20(5): 724-728.

2. Mukherjee R, Ram GC. Evalution of mammary gland immunity and therapeutic potential of Tinospora cordifolia against bovine subclinical mastitis. Tropical Animal Health Production. 2010; 42(4):645-651.

3. Mukherje R, Dash PK, Ram GC. Immunotherapeutic potencial of Ocimum sanctum (L) in bovine subclinical mastitis. Research in Veterinary Science. 2005; 79(1):37-43.

4. Schuch LFD, Wiest JM, Coimbra HS, Prestes LS, Toni L, Lemos JS. Cinética da atividade Antibacteriana in vitro de extratos naturais frente a micro-organismos relacionados a mastite bovina. Ciência Animal Brasileira. 2008; 9(1):161-169.

5. Schiavon DBA, Schuch LFD, Oyarzabal MEB, Prestes LS, Zani JL, Hartwig CA. Aplicación de plantas medicinales para La antisepsia de pezones de vacas posordeño. Revista Cubana de Plantas Medicinales. 2011; 16(3):253-259.

6. Lorenzi H, Abreu FJM, (2 ed). Plantas Medicinais do Brasil: Nativas e Exóticas. Nova Odessa, SP: Instituto Plantarum, 544p, 2008.

7. El-Massry KF, El-Ghorab AH, Shaaban HÁ, Shibamoto T. Chemical compositions and antioxidant/ antimicrobial activities of various samples prepared from Schinus terebinthifolius leaves cultivated in Egypt. Journal of Agrocultural and Food Chemistry. 2009; 57(12):5265-5270.

8. Freires IA, Alves LA, Jovito VC, Almeida LFD, de Castro RD, Padilha WWN. Atividades antibacteriana e antiaderente in vitro de tinturas de Schinus terebinthinfolius (Aroeira) e Solidago microglossa (Arnica) frente a bactérias formadoras do biofilme dentário. Odontologia Clónico-Científica. 2010; 9(2):139-143.

9. Ribeiro MG, Geraldo JS, Langoni H, Lara GHB, Siqueira AK, Salerno T, Fernandes MC. Micro-organismos patogênicos, celularidade e resíduos de antimicrobianos no leite bovino produzido no sistema orgânico. Pesquisa Veterinária Brasileira. 2009; 29(1): 52-58.

10. Quinn PJ, Carter ME, Markey B, Carter GR. Clinical Veterinary Microbiology. Londres (England): Wolfe; $648 \mathrm{p}, 1998$.

11. Neijenhuis F, Barkema HW, Hogeveen H, Noordhuizen JPTM. Classification and longitudinal examination of callused teat-ends in dairy cows. Journal Dairy Science. 2000; 83(12):2795-2804.

12. Schalm O, Noorlander D. Experiments and observations leading to the development of California mastitis test. Journal American Veterinary Medicine Association. 1957; 130(5):199-204.

13. Oyarzabal MEB, Schuch LFD, Prestes LS, Schiavon DBA, Rodrigues MRA, Mello JRB. Actividad antimicrobiana de eceite esencial de Origanum vulgare L. ante bacterias aisladas en leche de bovino. Revista Cubana de Plantas Medicinales. 2001; 16(3):260-266.

14. Langoni H, Sakiyama TP, Guimarães FF, Menozzi BD, Silva RC. Aspectos citológicos e microbiológicos do leite em propriedades no sistema orgânico de produção. Pesquisa Veterinária Brasileira. 2009; 29(11):881886.

15. Della Libera AMMP, Souza FN, Blagitz MG, Batista CF. Avaliação de indicadores inflamatórios no diagnóstico da mastite bovina. Arquivos do Instituto Biológico. 2011; 78(2):297-300.

16. Bhutto AL, Murray RD, Woldehiwet Z. California mastitis test scores as indicators of subclinical intramammary infections at the end of lactation in dairy cows. Research in Veterinary Science. 2012; 92(1):13-17.

17. Shitandi A, Kihumbu G. Assesment of the California mastitis test usage in smallholder dairy herds and risk of violative antimicrobial residues. Journal Veterinary Science. 2004; 5(1):5-9.

18. Oliveira JMB, Vanderlei DR, Moraes WS, Brandespim DF, Mota RA, Oliveira AA, Medeiros ES, Pinheiro 
Júnior JW. Fatores de Risco associados a mastite bovina na microrregião Garanhuns, Pernambuco. Pesquisa Veterinária Brasileira. 2012; 32(5):391-395.

19. Gundelach Y, Kalscheuer E, Hamann H, Hoedemaker M. Risk factors associated with bacteriological cure, new infection, and incidence of clinical mastitis after dry cow therapy with three different antibiotics. Journal Veterinary Science 2011; 12(3):227-233.

20. Park YK, Fox LK, Hancock DD, McMahan W, Park YH. Prevalence and antibiotic resistence of mastitis payhogens isolated from dairy herds transitioning to organic management. Journal Veterinary Science. 2012; 13(1):103-105.

21. Silva AB, Silva T, Franco ES, Rabelo AS, Lima ER, Mota RA, Câmara CAG, Pontes-Filho NT, Lima-Filho JV. Antibacterial activity, chemical composition, and cytotoxicity of leaf's essential oil from Brazilian pepper tree (Schinus terebinthifolius Raddi). Brazilian Journal of Microbiology. 2010; 41(1):158-163. 